\title{
Evaluation of efficacy and safety of Gas-O-Fast (Ajwain) in Amalpitta
}

\author{
Research Article
}

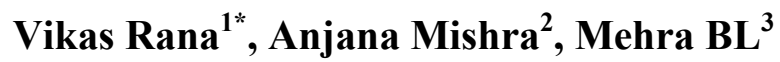 \\ 1. PG Scholar, 2. Reader, 3. Head of the Department, PG Department of Kayachikitsa, \\ R.G.G.P.G.Ayu. College \& Hospital, Paprola, H.P .
}

\begin{abstract}
Modern era's, changing lifestyle along with changing food habits and depending upon one's body constitution A mlapitta is one of the most common symptom (disease) seen in the society. Amlapitta is very distressing due to its chronic, relapsing and remittent nature. 'Hurry', 'Worry', and 'Curry' are the three main reasons for the disease. The industrialization, stress due to work, lack of exercise and faulty food habits leads to disturbance of Agni or metabolism which leads to many disorders, Amlapitta is one of them. Acidity refers to set of symptoms caused by an imbalance between the acid secreting mechanism of stomach and the protective mechanisms of gastric mucosa that ensure their safety. When due to some reason, there is excess production of acid by acid secreting glands of stomach, it results in condition known as Acidity. Acidity tends to have a much higher incidence in highly emotional and nervous individuals. Faulty lifestyle undoubtedly has a much higher role in this disease. Non-steroidal Anti Inflammatory Drugs (NSAID's) also predispose to gastric acidity. Prolonged acidity is responsible for symptoms like Dyspepsia, Heartburn and if not taken care of, the erosion of the lining of stomach or intestines result with the formation of Ulcers. Current research proposal is small step to explore evidence based therapeutic potential of Ayurvedic herbal formulation. Present short term clinical trial was designed to evaluate efficacy of Gas-O-Fast (Ajwain), when used in a dose of 3 sachet /day in volunteers. Drug was given to the patients of dyspepsia for 30 days. It is evident that improvement in symptoms of Amalpitta (Non ulcer dyspepsia) was statistically highly significant without any side effects/ toxic effects of formulation.
\end{abstract}

Keywords: Am lapitta, Acidity, Gas-O-Fast (Ajwain), Non ulcer dyspepsia.

\section{Introduction}

Amlapitta is the disease of Annavaha Srotas.(2) Amlapitta is one of disease due to Agni Vaikritya leading to production of Ama. Agni and pitta are the main factors responsible for digestion, due to their abnormality, food is not properly digested and produces the Aama, which is acidic in nature. Annavisha produced due to Ajirna when mixes with Pittadi Dosha, lodges in Aamashaya and produces the Amlapittadi diseases(2). Person gets various symptoms including Amla udgara (sour and bitter eructation), Utklesha (nausea) and Udar Adhmana (abdominal distension) etc. This syndrome is known as $\operatorname{Amlapitta}(\mathrm{Ma}$. Ni. $51 / 2) .(1,5)$

This is basically a disease of gastro-intestinal tract and due to abnormal secretions of gastric and pancreatic enzymes it has been described as acid peptic disorder.(8) A mlapitta can be linked to wide spectrum of diseases like Acute Gastritis, Non-Ulcer Dyspepsia, Acid Peptic disorder, Gastro-esophageal Reflux disease and Achlorhydria. Peptic ulcers have similar symptoms related to Amlapitta. But the patho-physiology and

*Corresponding Author:

Vikas Rana,

PG scholar, PG Department of Kayachikitsa,

R.G.G.P.G.Ayu. College \& Hospital,

Paprola, Himachal Pradesh

Email address: vikas8rana@gmail.com histopathology said that ulcers can't be included in Amlapitta, rather it may be a complication of Amlapitta. So, the acid peptic disease without peptic ulcer can be included in Amlapitta i.e. Non-Ulcer Dyspepsia. It is a common complaint of patients visiting OPD in hospital set up. Functional or idiopathic dyspepsia commonly occurs as a chronic digestive disorder affecting $20-40 \%$ of general population.(9) This condition is characterized by a recurring variable cluster of upper abdominal symptoms associated with food intake for which no evidence of organic disease can be found. This includes a variety of upper gastrointestinal symptoms like epigastric / retrosternal burning sensation, sour eructation / belching, indigestion, nausea, vomiting and distension of abdomen. $(7,9)$

The gastric acid hyper secretion (Acidity) is one of the probable cause of dyspepsia. This can be caused by an imbalance between the acid secreting mechanism of stomach and the protective mechanism of gastric mucosa that ensure their safety of gastric mucosa. Incidence of this disease is more in highly emotional and nervous persons and individuals with faulty dietary habits e.g. fast foods and spicy foods. Indiscriminate use of several therapeutic agents like steroids, NSAID's, addiction to smoking, alcohol, taking tea and coffee several times are chiefly associated with this disease. These faulty dietary habits predispose individuals for hyperacidity.(7)

Though in modern medicine, plenty of new drugs are available to manage non-ulcer dyspepsia but all the drugs provide only symptomatic relief and none 
of them possess curative potentials. As these drugs are required to be consumed for a longer duration, so a lot of untoward effects are also inevitable. Hence in order to overcome these issues present study was planned to explore the efficacy of very simple, safe and cost effective herbal formulation to counteract the symptoms of Amlapitta. Gas-O-fast (Ajwain) a preparation prepared by M/S COPMED PHARMACEUTICALS PVT. LTD. which contains Svarjiksara (shudh), Nimbukamlam (Shushkam),(3) Ajwain and Excipients (Saccharin Sodium, Permitted Sweetener, Black salt, Permitted Colour) is used to relieve the symptoms of Amlapitta. Drug was given to the patients of Amlapitta for 30 days, it proved highly effective and no untoward effect is noted.

\section{Aims and Objectives}

1. To evaluate the efficacy of Gas-O-Fast (Ajwain) in the management of Amlapitta.

2 . To evaluate the safety of drug.

\section{Material and Method}

The study was conducted in compliance with good clinical practice (GCP) guidelines and other applicable regulations.

\section{Selection of the Patients}

A total of 30 patients were assessed of Amalpitta (Non ulcer Dyspepsia) fulfilling the diagnostic criteria having frequent complaints of dyspepsia irrespective of the cause, were registered from hospital wing of Kayachikitsa, Rajiv Gandhi Govt. P.G. Ayurvedic Hospital, Paprola Distt. Kangra H.P.

Trial patients of either sex were selected between age group of 18-70 years. Routine blood examinations (Hbgm\%, TCL, DLC, ESR, FBS \& RFT) were carried out in order to rule out any other pathology and monitor normal values of blood during trial period. Trial Subjects were detailed about nature of trial and informed consent was obtained.

\section{Inclusion Criteria}

- Patients in the age group between 18 to 70 years of either sex.

- Patients able to provide informed consent.

- Patients were included on the basis of signs and symptoms of Amalpitta (Non ulcer dyspepsia) epigastric pain, burning sensation over epigastriun/ retrosternal region, sour/ bitter eructation, nausea, vomiting, indigestion and abdominal distension.

\section{Exclusion Criteria}

- Patients not willing for the trial or not ready to give informed consent.

- Patients with Peptic ulcer disease, IBS and past history of gastric surgery.

- Patients having malignancy, hypertension, cardiac problem, hepatic disorders, renal disorders, uncontrolled diabetes mellitus and other co-morbid diseases.

Table no. 1: Trial Drug "Gas-o-Fast (Ajwain)" and its administration

\begin{tabular}{|l|l|}
\hline Formulation Name & Gas-o-Fast (Ajwain) \\
\hline Pharmaceutical form & Powder \\
\hline Dose & $\begin{array}{l}\text { 1 sachet in a glass of } \\
\text { cold water }\end{array}$ \\
\hline Route of administration & Oral \\
\hline $\begin{array}{l}\text { Frequency of admin- } \\
\text { istration }\end{array}$ & $\begin{array}{l}\text { Twice a day and one as } \\
\text { when required }\end{array}$ \\
\hline $\begin{array}{l}\text { Duration of administra- } \\
\text { tion }\end{array}$ & 30 days \\
\hline Ingredients & In table below \\
\hline Storage & $\begin{array}{l}\text { Moisture free environ- } \\
\text { ment }\end{array}$ \\
\hline
\end{tabular}

\section{Constituents:}

The trial formulations contained following herbs and in the quantity mentioned. The formulation was prepared by $\mathrm{M} / \mathrm{S}$ COPMED PHARMACEUTICALS PVT.LTD.

Table no. 2- Each $5 \mathrm{gm}$ of sachet contains -

\begin{tabular}{|l|l|l|l|l|l|l|}
\hline $\begin{array}{l}\text { Sr. } \\
\text { No }\end{array}$ & Drug & Latin name & $\begin{array}{l}\text { Part } \\
\text { used }\end{array}$ & $\begin{array}{l}\text { Dose/ } \\
\text { sachet }\end{array}$ & $\begin{array}{l}\text { Ref. Book } \\
\text { Page no. }\end{array}$ & Guna Karma \\
\hline 1. & Svarjiksara (Shudh) & - & Churna & $\begin{array}{l}2.68 \\
\text { gm }\end{array}$ & $\begin{array}{l}\text { Ras Taringini } \\
\text { P-313-315 }\end{array}$ & $\begin{array}{l}\text { Pachaka, Deepana, } \\
\text { Amlapitta Shamaka }\end{array}$ \\
\hline 2. & $\begin{array}{l}\text { Nimbu kamlam } \\
\text { (Shushkam) }\end{array}$ & Citrus medica L. & $\begin{array}{l}\text { Fruit } \\
\text { extract }\end{array}$ & $\begin{array}{l}2.24 \\
\text { gm }\end{array}$ & $\begin{array}{l}\text { Ras taringini } \\
\text { P- 316 }\end{array}$ & $\begin{array}{l}\text { Pachaka, Deepana, } \\
\text { Amlapitta Shamaka }\end{array}$ \\
\hline 3. & $\begin{array}{l}\text { Ajwain } \\
\text { Trachyspermum }\end{array}$ & Seeds & $\begin{array}{l}104 \\
\text { mg }\end{array}$ & $\begin{array}{l}\text { Bhavprakasha } \\
\text { Nigantu }\end{array}$ & $\begin{array}{l}\text { Pachaka, Deepana, } \\
\text { Amlapitta Shamaka }\end{array}$ \\
\hline 4. & $\begin{array}{l}\text { Excipients: } \\
\text { Saccharin Sodium, Black } \\
\text { salt, } \\
\text { Permitted sweetener, } \\
\text { Permitted color }\end{array}$ & & $\begin{array}{l}\text { Indian } \\
\text { Pharmacopeia }\end{array}$ & \\
\hline
\end{tabular}

\section{Period of Clinical Study}

Commencement of trial : Completion of trial
January 2015

March 2015 


\section{Groups}

The study was done in single trial group. It was open trial with voluntary participation of patients.

\section{Criteria of Assessment}

Scoring system was adopted for assessment of various subjective features:

1.Daha (Epigastric \& retrosternal burning) Grade

No daha

Mild degree

Moderate degree relieved by milk, 2 antacid

Severe degree involving hrita, kantha \& 3 relieved

After digestion of food \& vomiting 4 severe degree not relieved at all

2. Amla udgara (Bitter eructation)

No amla udgara

Sometimes during day

Moderate degree

Severe degree disturbing patients daily 3 routine

Small amount of fluid regurgitates to 4 mouth

3. Utklesha (Nausea)

Absent

Occasional desire to vomit

Frequent desire to vomit

Continuous desire to vomit

Continuous desire to vomit with profuse 4 water brash

4. Avipaka (Indigestion)

No indigestion

Occurs 2-3 times/week

Occurs daily but not severe

More than 2-3 ajirna ahara lakshna 3

Severe indigestion which does not 4 subside without medicine

5. Chhardi (Vomiting)

No vomiting

Feels sense of nausea and vomits 1 occasionally

Frequency not more than 2-3 per week 2

Frequency between 4-6 per week and 3 comes whenever

Pain is aggravated and Frequency is 4 daily

6. Udar adhman (Flatulence)

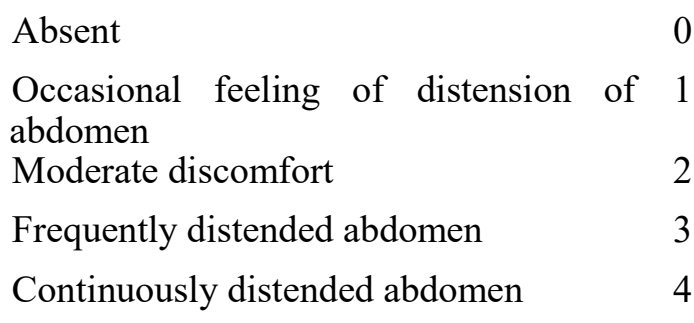

Statistical method used

t-test (IBM SPSS STATISTICS 20)

\section{Results and Observation}

30 Patients were registered and all turned for follow up after 30 days. As per assessment criteria out of 30 patients, 15 patients showed complete, 7 patients showed moderate and 3 patients showed mild improvement in symptoms whereas 5 patients showed no improvement. Statistical analysis showed most of the variables kept in assessment criteria had statistically significant improved $(p<0.001)$. The patients of all ages and both the sex groups reported improvement in their complaints. No side/adverse effect of the therapy was reported in any patient.

\section{Symptom wise details-}

\section{Daha (Epigastric \& retrosternal burning)}

Mean Score before treatment was 3.1which fell to 0.7 giving improvement of $74.19 \%$ which was statistically highly significant with t value of 19.3 and $\mathrm{P}<0.001$.

\section{Amla udgara (Bitter eructation)}

Mean Score before treatment was 2.33 which fell to 0.7 giving improvement of $66.9 \%$ which was statistically highly significant with $t$ value of 9.56 and $\mathrm{P}<0.001$.

\section{Utklesha (Nausea)}

Mean Score before treatment was 2.93 which fell to 1.70 giving improvement of $41.9 \%$ which was statistically highly significant with $t$ value of 9.2 and $\mathrm{P}<0.001$.

\section{Avipaka (Indigestion)}

Mean Score before treatment was 2.93 which fell to 2.70 giving improvement of $7.84 \%$ which was statistically insignificant with $t$ value of 10.283 and $\mathrm{P}>0.05$.

\section{Chhardi (Vomiting)}

Mean Score before treatment was 2.16 which fell to 2.03 giving improvement of $6.01 \%$ which was statistically insignificant with $t$ value of 1.68 and $\mathrm{P}>0.05$.

\section{Udar adhman (Flatulence)}

Mean Score before treatment was 2.13 which fell to 0.53 giving improvement of $75.11 \%$ which was statistically highly significant with $t$ value of 6.24 and $\mathrm{P}<0.001$. 


\section{International Journal of Ayurvedic Medicine, 2017, 8(3), 138-142}

Table no. 3 Assessment of Patients: (Symptomatic improvement)

\begin{tabular}{|l|l|l|l|l|l|l|l|}
\hline Sr. & Assessment criteria & \multirow{2}{*}{$\begin{array}{l}\text { No. of } \\
\text { Potients }\end{array}$} & & \multicolumn{5}{|c|}{ Improvement } \\
\cline { 7 - 8 } & & & No. & Mild & Moderate & Complete & \% Relief \\
\hline 1 & $\begin{array}{l}\text { Daha } \\
\text { (Epigastric \& retrosternal burning) }\end{array}$ & 27 & $4(15 \%)$ & 3 & 5 & 15 & $85 \%$ \\
\hline 2 & Amla udgara (Bitter eructation) & 28 & $4(14 \%)$ & 4 & 6 & 14 & $86 \%$ \\
\hline 3 & Utklesha (Nausea) & 22 & $4(18 \%)$ & 1 & 5 & 12 & $82 \%$ \\
\hline 4 & Avipaka (Indigestion) & 19 & $6(31 \%)$ & 4 & 9 & - & $69 \%$ \\
\hline 5 & Chhardi (Vomiting) & 14 & $6(42 \%)$ & 3 & 5 & - & $58 \%$ \\
\hline 6 & Udar adhman (Flatulence) & 23 & $4(17 \%)$ & 3 & 4 & 12 & $83 \%$ \\
\hline
\end{tabular}

Table no. 4 Effect of Gas-O-fast (Ajwain) on clinical features of Amalpitta in 30 days

\begin{tabular}{|c|c|c|c|c|c|c|c|c|}
\hline \multirow{2}{*}{$\begin{array}{l}\text { Sr. } \\
\text { No. }\end{array}$} & \multirow[t]{2}{*}{ Assessment Criteria } & \multicolumn{2}{|c|}{ Mean } & \multirow{2}{*}{$\begin{array}{l}\% \\
\text { Diff. }\end{array}$} & \multirow[t]{2}{*}{$\overline{\text { S.D } \pm}$} & \multirow{2}{*}{$\begin{array}{l}\mathbf{S . E} \\
\pm\end{array}$} & \multirow[t]{2}{*}{ 't' } & \multirow[t]{2}{*}{$\mathbf{p}$} \\
\hline & & BT & AT & & & & & \\
\hline 1 & Daha (Epigastric \& retrosternal burning) & 3.1 & 0.7 & 74.19 & 0.66 & 0.12 & 19.3 & $<0.001$ \\
\hline 2 & Amla udgara (Bitter eructation) & 2.33 & 0.7 & 66.95 & 0.89 & 0.16 & 9.56 & $<0.001$ \\
\hline 3 & Utklesha (Nausea) & 2.93 & 1.70 & 41.9 & 0.72 & 0.13 & 9.2 & $<0.01$ \\
\hline 4 & Avipaka (Indigestion) & 2.93 & 2.70 & 7.84 & 0.50 & 0.09 & 2.53 & $>0.05$ \\
\hline 5 & Chhardi (Vomiting) & 2.16 & 2.03 & 6.01 & 0.43 & 0.07 & 1.68 & $>0.05$ \\
\hline 6 & Udar adhman (Flatulence) & 2.13 & 0.53 & 75.11 & 1.40 & 0.25 & 6.24 & $<0.001$ \\
\hline
\end{tabular}

BT: Before treatment; AT: After treatment; \% Diff.: Difference of mean; S.D: Standard deviation; S.E: Standard Error

Table 5: Overall Effect of Therapy

\begin{tabular}{|l|l|l|}
\hline Overall Effect of Therapy & No. of patients & \% Relief \\
\hline Complete Improvement & 15 & 50 \\
\hline Moderate Improvement & 7 & 23.3 \\
\hline Mild Improvement & 3 & 10 \\
\hline No Improvement & 5 & 16.7 \\
\hline
\end{tabular}

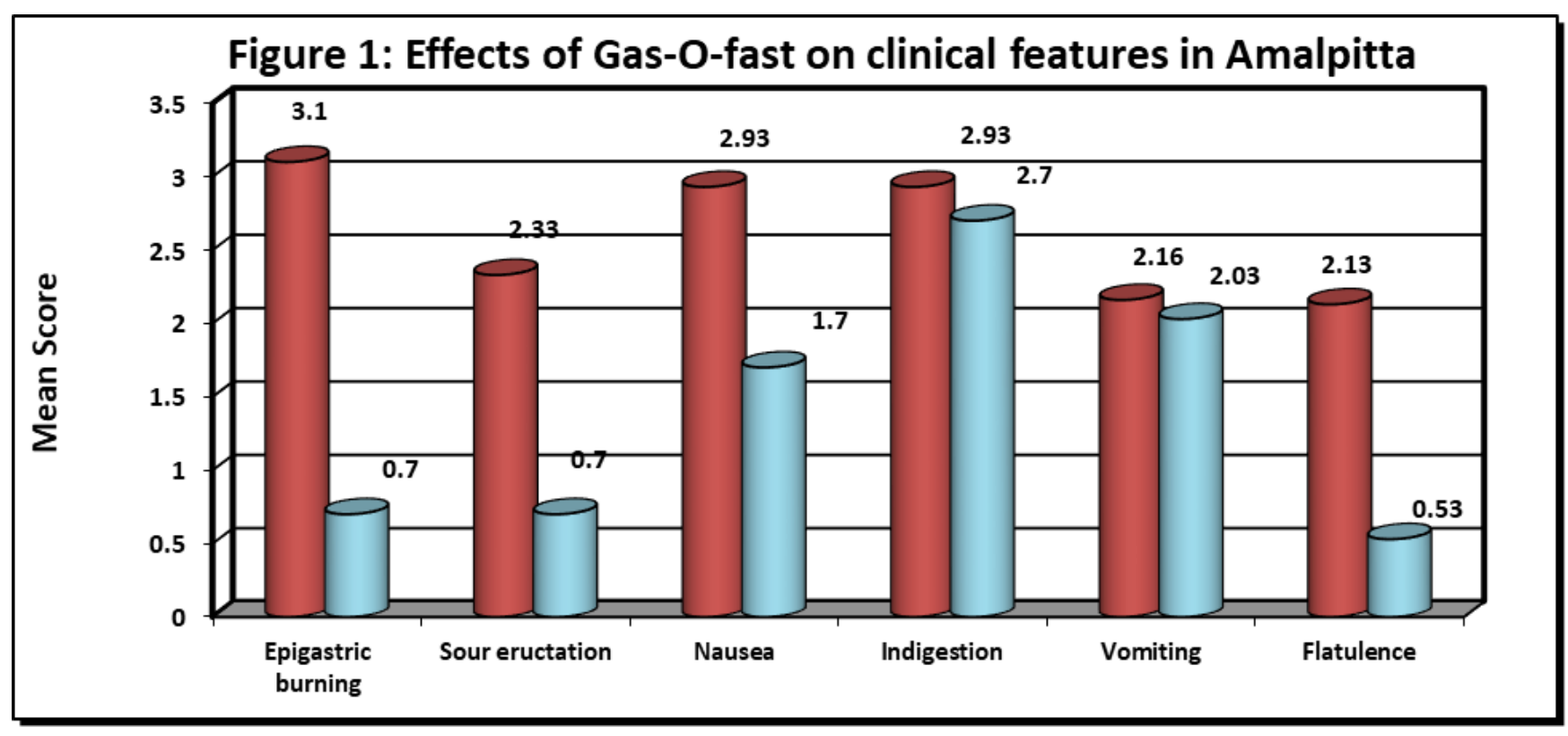




\section{Discussion}

Most of patients reported relief in symptoms of Amalpitta. Symptomatic relief of burning sensation was reported by the patients after $2^{\text {nd }}$ dose of the drug and at the end of $4^{\text {th }}$ week there were few negligible symptoms of dyspepsia. The relief in epigastric burning, sour eructation, nausea and flatulence was remarkable. The patients of all ages and both the sex groups reported relief in their complaints. It is evident that improvement in symptoms of Amalpitta (Non ulcer dyspepsia) was statistically highly significant without any side effects/ toxic effects of formulation.

Pathya and Apathya are very important factors in the management of gastro intestinal disorders. The patients were strictly asked to modify their dietary habits about do's and don'ts in relation to Ahara and Vihara during clinical study, which may have great influence in relief of symptoms.(12) Most of the ingredients of trial drug have deepana, pachaka and amlapitta shamaka properties.(5) As nonfunctioning state of Agni is also responsible for illness which is corrected with deepana and pachaka guna of drugs. Rastaringini described the properties of Svarjiksara and Nimbukamlam Svarjiksara. Svarjiksara has Amalpitta and amla udgara shamaka properties with cold water. Nimbukamlam Svarjiksara alleviates bitter eructation and improving digestive power.(2) The presence of Svarjiksara and Citrus medica in drug has probably helped in neutralizing the gastric acid and thereby relieving the symptoms of non-ulcer dyspepsia.

Trachyspermum ammi (Ajwain) increases the secretion of gastric acid and also enhance the activity of digestive enzymes. It also has antiulcer property. The seeds contain $2-4.4 \%$ brown coloured oil, thymol the main constituent of oil used in gastrointestinal ailments. The seeds are quite effective for digestive problems like indigestion, acidity, bloating, flatulence and stomach ache. The traditional therapeutic uses of Trachyspermum ammi include galactogogue, stomachic, carminative, expectorant, antiseptic and antimicrobial. (10)

\section{Conclusion}

From the above observations and discussion, it can be concluded that, Gas-O-Fast Ajwain is found to be very effective in the treatment of Amalpitta (Non ulcer dyspepsia). The present study emphasizes the effectiveness of GAS-O-FAST AJWAIN in the patients of Amalpitta (Non ulcer dyspepsia). Dyspepsia of recent onset and chronic nature in elderly patients needs to be evaluated and investigated completely. Remarkable relief is noted in epigastric burning, sour/ bitter eructation, nausea and flatulence. The drugs used in this formulation also help in improving digestion and metabolism by their well-known effect at the level of agni ( digestive fire) thus targeting the root cause of various gastrointestinal disorders.

Financial support and sponsorship-

- Rajiv Gandhi Govt.P.G.Ayu.College and Hospital, Paprola H.P.

- M/S COPMED PHARMACEUTICALS PVT.LTD.

\section{References}

1. Madhavakara. MadhavaNidana (Madhukosa commentary) 2nd Part $30^{\text {th }}$ edition, Shriyadunandanopadhyaya editor. Chaukhambha Sanskrita Sansthana Varanasi; 2000.

2. Prof. Ajay Kumar Sharma. Kaya Chikitsa-2nd part. Chaukhambha orientalia, Varanasi.

3. Sadanand Sharma. Rasatarangini. 11th Edition. Edited by Kashi Nath Shastri, Motilal Banarasi Das, New Delhi; 1982. Chapter 12, 313-316p.

4. Indradeva Tripathi. Rasendra Sarasangraha with Rasa Vidyotini commentary, 2nd edition, Chaukhambha Orientalia, Varanasi; 1998.

5. Prof. K.R. Srikantha Murthy. Bhavaprakasa by Bhavamisra (including Nighantu portion), (Tr.), Krishnadas Academy, Varanasi, Dhatvadivarga.

6. Pandit Shri. Lalchandra Vaidya. Bhaisajya Ratnavali $8^{\text {th }}$ edition, Shri Govindadas Vicharita Delhi.

7. Sidharth N. Shah. API Textbook of Medicine $8^{\text {th }}$ edition vol.1, Chief Association of Physicians of India, Mumbai 2008.

8. Arthur C. Guyton, John E. Hall, Text book of Medical Physiology $9^{\text {th }}$ edition Elsevier Inc; 1998, USA.

9. Brian R.Walker, Nicki R. Colledge, Stuart H. Ralston-Davidsons Principles and Practice of Medicine, Publisher-Elsevier $22^{\text {nd }}$ edition 2014.

10. Kamal Jeet et al. IRJP 2012 - Trachyspermum ammi (Ajwain): A Comprehensive review

11. Prakash BR. Study of non-ulcer dyspepsia and possible treatment with a herbomineral formulation: An open clinical trial. Indian Journal of Clinical Practice 2002; 12(8):49-52.

12. Verma Manu et al.; A clinical study to evaluate the efficacy of an Ayurvedic formulation (Ayucid) in the management of Amlapitta w.s.r. to Non-Ulcer Dyspepsia, Thesis 2017 P.G.Dept. of Kayachikitsa. 